\title{
Road-killed mammals provide insight into tick-borne bacterial pathogen communities within urban habitats
}

\author{
Sándor Szekeres ${ }^{1}$ | Arieke Docters van Leeuwen ${ }^{2}$ | Evelin Tóth ${ }^{1}$ | Gábor Majoros ${ }^{1}$ | \\ Hein Sprong ${ }^{2}$ | Gábor Földvári ${ }^{1,3}$
}

${ }^{1}$ Department of Parasitology and Zoology, University of Veterinary Medicine Budapest, Budapest, Hungary

${ }^{2}$ Laboratory for Zoonoses and Environmental Microbiology, National Institute for Public Health and Environment, Bilthoven, The Netherlands

${ }^{3}$ Evolutionary Systems Research Group, Centre for Ecological Research, Hungarian Academy of Sciences, Tihany, Hungary

\section{Correspondence}

Gábor Földvári, Department of Parasitology and Zoology, University of Veterinary Medicine Budapest, Budapest, Hungary.

Email: FoldvariGabor@gmx.de

Funding information

Hungarian Eötvös Scholarship; EurNegVec Cost Action, Grant/Award Number: TD1303; János Bolyai Research Scholarship of the Hungarian Academy of Sciences; Hungarian Ministry of Human Resources, Grant/Award Number: 12190/2017/FEKUTSTRAT, 11475-4/2016/FEKUT; In the light of evolution: theories and solutions, Grant/ Award Number: GINOP-2.3.2-15-201600057

\begin{abstract}
Small- and medium-sized mammals play an important role in the life cycle of tickborne pathogens in urban habitats. Our aim was to apply the general protocol, DAMA (documentation-assessment-monitoring-action), which is an integrated proposal to build a proactive capacity to understand, anticipate, and respond to the outcomes of accelerating environmental change. Here we tested whether road-killed carcasses in urban areas are useful sources of tissue and parasite samples to investigate these species' contribution to the epidemiology of vector-borne diseases. We collected 29 road-killed and 6 carcasses with different causes of mortality (23 northern white-breasted hedgehogs and 12 from seven other mammal species) mainly from Budapest, Hungary. We used quantitative and conventional PCRs to determine pathogens in 90 collected tissues (52 from hedgehogs; 38 from other species) and 417 ticks that were only found on hedgehogs. Tissue samples revealed a wide range of bacteria including human zoonotic pathogens identified as Anaplasma phagocytophilum ecotype I, Borrelia afzelii, B. spielmanii, Borrelia miyamotoi, Rickettsia helvetica, and Bartonella species. Among the 23 collected hedgehog carcasses, 17 (74\%) were infected with A. phagocytophilum, 6 (26\%) with Borrelia burgdorferi s.l., 12 (52\%) with R. helvetica, and 15 (65\%) with Rickettsia sp. Furthermore, we report the first detection of Rickettsia sp. infection in European moles and lesser weasel and $R$. helvetica in stone marten. Through sequencing $B$. afzelii, $R$. helvetica, $R$. monacensis and A. phagocytophilum ecotype I were identified in the ticks removed from the carcasses. We showed that road-killed urban mammal species are exposed to multiple tick-borne pathogens but further studies have to clarify whether they, in fact, also have a role in their maintenance and spread. Our study also demonstrates that roadkill can be used in the risk assessment of potential human infection and in the implementation of the DAMA protocol.

KEYWORDS

DAMA protocol, eco-epidemiology, roadkill, tick-borne pathogens, urban mammals
\end{abstract}

\section{BACKGROUND}

Many of the approximately 700 known hard tick species (Acari, Ixodidae) act as vectors of pathogens with veterinary and medical relevance. Wild and urban animals may play an important role in the epidemiology of tick-borne diseases (TBDs) and in the spread (to new regions) and maintenance of tick populations. In Hungary, several wildlife species have been found to harbour genetic 
material of various tick-borne pathogens potentially affecting both domestic animals and humans (Földvári et al., 2014; Hornok et al., 2014, 2015; Szekeres et al., 2015a,b; Tolnai, Sréter-Lancz, \& Sréter, 2015). Within Budapest, the capital of Hungary, 48 different mammal species from bats (Chiroptera) to wild boar (Sus scrofa) have been recorded since 1990 (Tóth-Ronkay et al., 2015). Hedgehogs and squirrels can reach higher densities in urbanized areas than in wild habitats (Reeve, 1994; Tóth-Ronkay et al., 2015). They are living in surrounding forests, bigger city parks, cemeteries and also close to human dwellings, e.g., hedgehogs and squirrels in the backyards or martens in the lofts. The trend to increase the urban green areas for recreation, reduce air and noise pollution, and mitigate the frequent fluctuations of humidity and heat is improving the well-being of the citizens. On the other hand, these green areas can serve as important habitats for several wildlife species (e.g., in winter time or when food is scarce). These animals often disperse when looking for new territories and can spread ticks from natural habitats to the heart of the cities and can help to maintain a stable tick and tick-borne pathogen population. As an example hedgehogs can maintain the whole cycle of Ixodes ricinus and several tick-borne pathogens as well (Földvári et al., 2011, 2014; Krawczyk et al., 2015). For urban animals, additional hazards of the city life such as vehicles on the roads are frequent cause of death. The resulting carcasses may provide a convenient, noninvasive, and useful source of samples for research projects targeting tick-borne pathogens in urban habitats. Exploring the spectrum of pathogens in roadkill could help to assess possible risk factors of human infection.

Our aim was to apply the general protocol, DAMA (documentation-assessment-monitoring-action), which is an integrated proposal to build a proactive capacity to understand, anticipate, and respond to the outcomes of accelerating environmental change (Brooks et al., 2014). In this article, we focused on documentation and assessment of communities of tick-borne bacterial pathogens in ectoparasites and tissue samples collected from mammalian roadkills in urban areas.

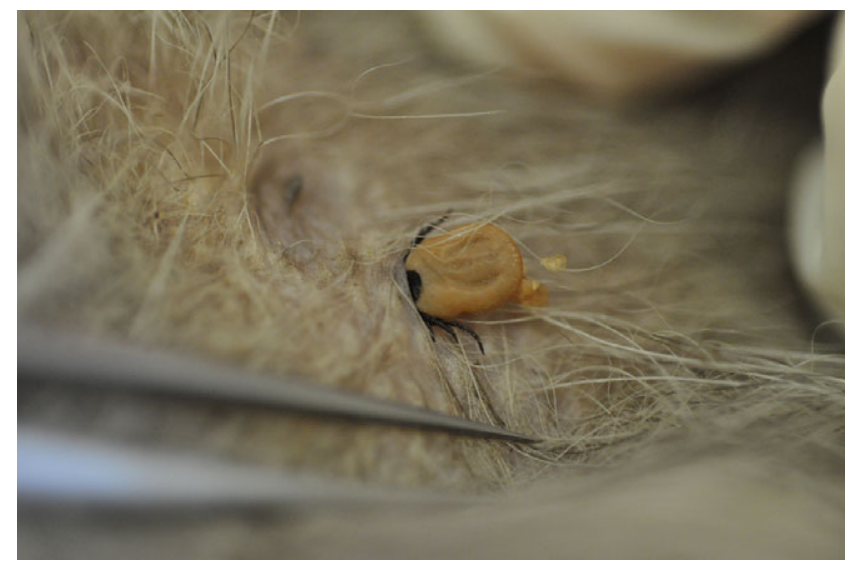

FIGURE 2 Partly engorged Ixodes ricinus female attached to the abdomen of a road-killed hedgehog [Colour figure can be viewed at wileyonlinelibrary.com]

\section{METHODS}

\subsection{Sample collection}

Between April and August of 2015, we collected 29 road-killed mammals, mainly hedgehogs with the help of volunteers mainly from Budapest and some other locations around Hungary. In addition, we also collected six animals that died for other reasons (e.g., caught by cats, for details see Supporting Information Table S1). Volunteers were asked personally or through social media to inform us about road-hit carcasses in urban areas and we collected the samples. The study was carried out with the official permission from the MiddleDanube-Valley Inspectorate for Environmental Protection, Nature Conservation and Water Management, Hungary (KTF:4018-4/2015). We bagged carcasses on site and dissected them under laboratory conditions. We collected samples from various identifiable tissues (minimum: skin, maximum: five different tissues) paying attention to use sterilized or unused devices for every tissue sample. Blood was taken from the heart of fresh carcasses, and coagulated blood was

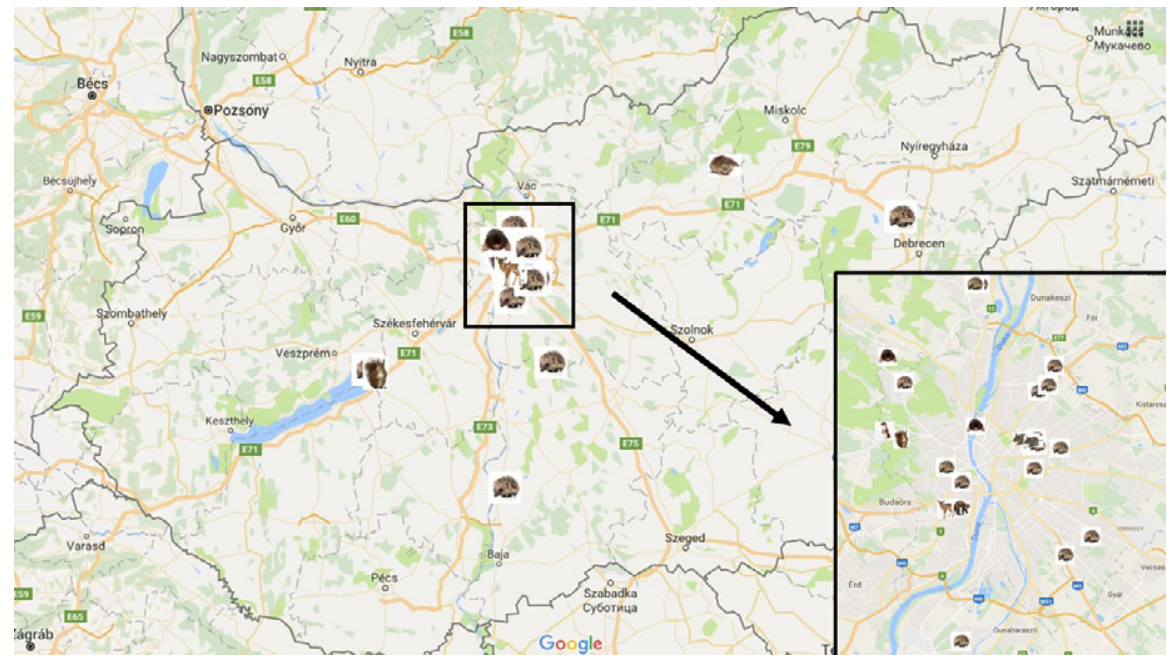

FIGURE 1 Locations of the studied road-killed urban mammals in Hungary. An online zoomable version of the map with details about each sample is available at: https://goo.gl/9eeZm7. Symbols represent one mammal specimen each from the following species: hedgehog: Erinaceus roumanicus; mole: Talpa europaea; squirrel: Sciurus vulgaris; mouse: Mus musculus; marten: Martes foina; weasel: Mustela nivalis; shrew: Crocidura suaveolens; roe deer: Capreolus capreolus [Colour figure can be viewed at wileyonlinelibrary.com] 
TABLE 1 Number, stage, and species of ticks removed from the collected hedgehog carcasses

\begin{tabular}{|c|c|c|c|c|c|c|c|c|c|}
\hline \multirow[b]{2}{*}{ Host code } & \multicolumn{4}{|c|}{ Ixodes ricinus } & \multicolumn{4}{|c|}{ Ixodes hexagonus } & \multirow[b]{2}{*}{ Sum } \\
\hline & Larva & Nymph & Female & Male & Larva & Nymph & Female & Male & \\
\hline $\mathrm{H} 1$ & - & 1 & - & - & - & - & - & - & 1 \\
\hline $\mathrm{H} 7$ & - & 87 & 10 & 4 & - & - & - & - & 101 \\
\hline H9 & - & - & 1 & 1 & - & - & - & - & 2 \\
\hline $\mathrm{H} 12$ & - & 10 & 1 & 1 & - & - & - & - & 12 \\
\hline H15 & - & 5 & 4 & - & - & - & - & - & 9 \\
\hline H16 & - & 15 & 1 & 1 & - & 41 & 2 & - & 60 \\
\hline $\mathrm{H} 21$ & - & - & 1 & 1 & - & - & - & - & 2 \\
\hline Sum & 37 & 278 & 31 & 16 & 7 & 46 & 2 & - & 417 \\
\hline
\end{tabular}

TABLE 2 Prevalence of tick-borne pathogens in tissue samples of small- and medium-sized mammals detected with real-time PCR. Can. N. mikurensis was not detected in any of the tissue samples

\begin{tabular}{|c|c|c|c|c|c|c|}
\hline & $\begin{array}{l}\text { Borrelia } \\
\text { burgdorferi s.l. }\end{array}$ & $\begin{array}{l}\text { Borrelia } \\
\text { miyamotoi }\end{array}$ & $\begin{array}{l}\text { Anaplasma } \\
\text { phagocytophilum }\end{array}$ & $\begin{array}{l}\text { Rickettsia } \\
\text { helvetica }\end{array}$ & $\begin{array}{l}\text { Rickettsia } \\
\text { sp. }\end{array}$ & Bartonella sp \\
\hline Mammal/Pathogen species & \multicolumn{6}{|c|}{ No. positive tissue samples/No. tested tissue samples/prevalence (\%) } \\
\hline European mole (Talpa europaea) & $0 / 15 / 0 \%$ & $0 / 15 / 0 \%$ & $0 / 15 / 0 \%$ & $0 / 15 / 0 \%$ & $1 / 15 / 7 \%$ & $9 / 15 / 60 \%$ \\
\hline Roe deer (Capreoulus capreolus) & $0 / 3 / 0 \%$ & $0 / 3 / 0 \%$ & $1 / 3 / 33 \%$ & $0 / 3 / 0 \%$ & $0 / 3 / 0 \%$ & $0 / 3 / 0 \%$ \\
\hline Lesser shrew (Crocidura suaveolens) & $0 / 3 / 0 \%$ & $0 / 3 / 0 \%$ & $1 / 3 / 33 \%$ & $0 / 3 / 0 \%$ & $0 / 3 / 0 \%$ & $0 / 3 / 0 \%$ \\
\hline Stone marten (Martes foina) & $0 / 2 / 0 \%$ & $0 / 2 / 0 \%$ & $0 / 2 / 0 \%$ & $1 / 2 / 50 \%$ & $0 / 2 / 0 \%$ & $0 / 2 / 0 \%$ \\
\hline Lesser weasel (Mustela nivalis) & $0 / 4 / 0 \%$ & $0 / 4 / 0 \%$ & $0 / 4 / 0 \%$ & $0 / 4 / 0 \%$ & $1 / 4 / 25 \%$ & $2 / 4 / 50 \%$ \\
\hline
\end{tabular}

Bold values indicate prevalence data.

taken from the body cavity in case of older carcasses if organs were not smashed. The species, date of collection, location, and the degree of body degradation (see categories in Table 3) were recorded. Before dissection, we thoroughly inspected the bag and the body surface at room temperature and collected all the ectoparasites and stored them in $70 \%$ ethanol at $4^{\circ} \mathrm{C}$ until further molecular analysis. Ticks were identified using standard identification keys (Hillyard, 1996; Nosek \& Sixl, 1972). Carcasses and the collected tissue samples were stored at $-20^{\circ} \mathrm{C}$.

\section{2 | DNA extraction}

DNA was extracted from the ticks individually (adults) or in pools (larvae by up to 10 ; nymphs by up to 5 ) with alkaline hydrolysis (Guy \& Stanek, 1991). All tick samples were tested. In pooled samples, pools comprised of ticks of the same species and from the same host individual. We used ISOLATE II Genomic DNA Kit (Bioline Reagents Ltd, London, UK) to isolate the nucleic acid from the tissue samples. A pea-sized sample was taken from all available organs and lysed without any mechanical disruption according to the manufacturer's instruction. The final elution volume was $100 \mu \mathrm{l}$. We stored the DNA samples at $-20^{\circ} \mathrm{C}$ until further molecular analysis.

\subsection{Polymerase chain reaction}

To determine whether the tissue or tick samples contained any pathogens, we used species or genus specific quantitative PCR (qPCR) assays. When a sample was positive with genus-specific reactions, we used conventional PCR and sequencing to specify the pathogen species. In the qPCR reactions, we used primers targeting the specific gene regions for Borrelia burgdorferi s.l. (ospA: outer surface protein A gene, flab: flagellin gene) (Heylen, Tijsse, Fonville, Matthysen, \& Sprong, 2013), Borrelia miyamotoi (flaB) (Hovius et al., 2013), Anaplasma phagocytophilum (msp2: major surface protein 2 gene) (Courtney, Kostelnik, Zeidner, \& Massung, 2004), Candidatus Neoehrlichia mikurensis (GroEL: heat shock protein gene) (Jahfari et al., 2012), Rickettsia helvetica (gltA: citrate synthase gene) (de Bruin et al., 2015), and Rickettsia sp. (gltA) (Stenos, Graves, \& Unsworth, 2005). 


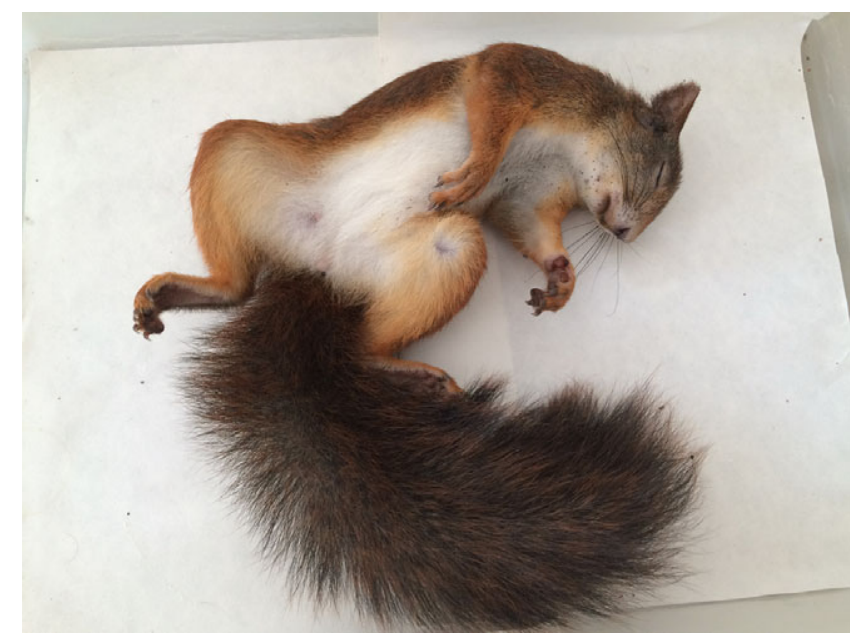

FIGURE 3 Seemingly intact road-killed red squirrel [Colour figure can be viewed at wileyonlinelibrary.com]

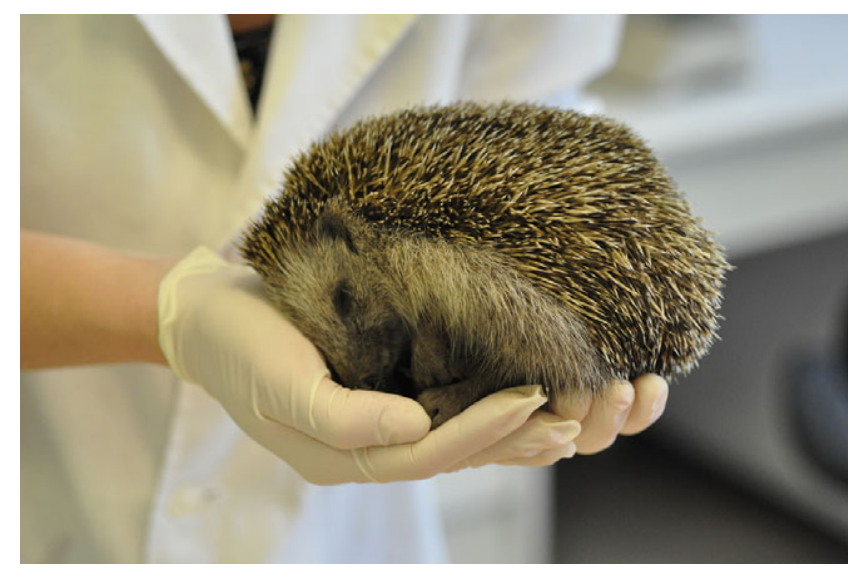

FIGURE 4 Seemingly intact road-killed northern white-breasted hedgehog [Colour figure can be viewed at wileyonlinelibrary.com]

Conventional PCRs were used for A. phagocytophilum (GroEL) (Jahfari et al., 2014), Borrelia burgdorferi s.l. (IGS: intergenic spacer) (Hansford, Fonville, Jahfari, Sprong, \& Medlock, 2015), Rickettsia (ompB) (Roux \& Raoult, 2000), and Bartonella species (gltA) (de Bruin et al., 2015). We used distilled water for negative and sequenced known positive samples for positive control.

\section{4 | Data analysis}

To calculate the pathogen prevalence in ticks, we used minimum infection rate, by calculating the prevalence considering that at least one individual is positive per positive pool.

\section{3 | RESULTS}

\section{1 | Collected samples}

Twenty-three road-killed northern white-breasted hedgehogs (Erinaceus roumanicus) and 12 other collected mammals from seven different species (e.g., European red squirrel and European mole) were

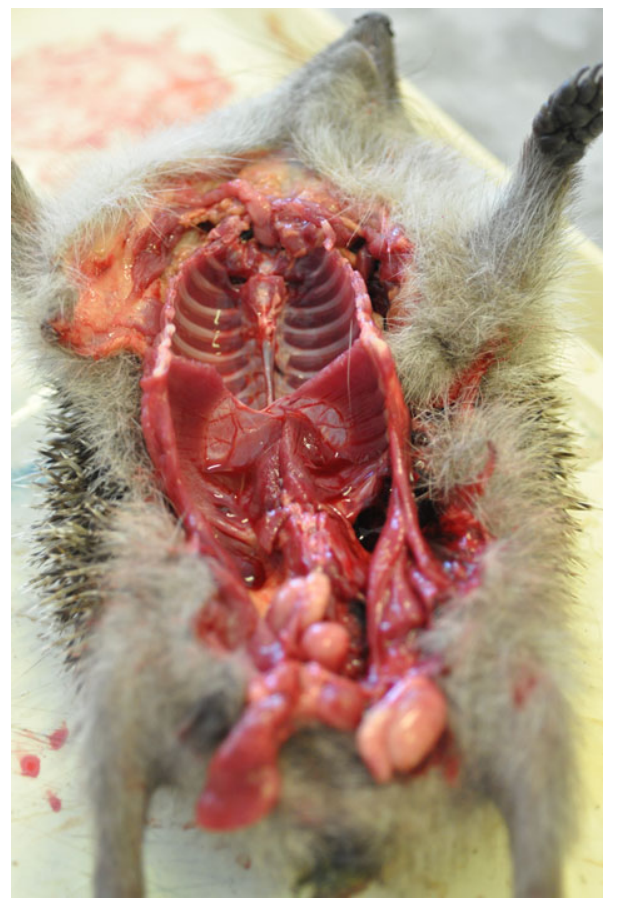

FIGURE 5 Dissection of a road-killed northern white-breasted hedgehog with organs in good condition (degree of degradation 1) [Colour figure can be viewed at wileyonlinelibrary.com]

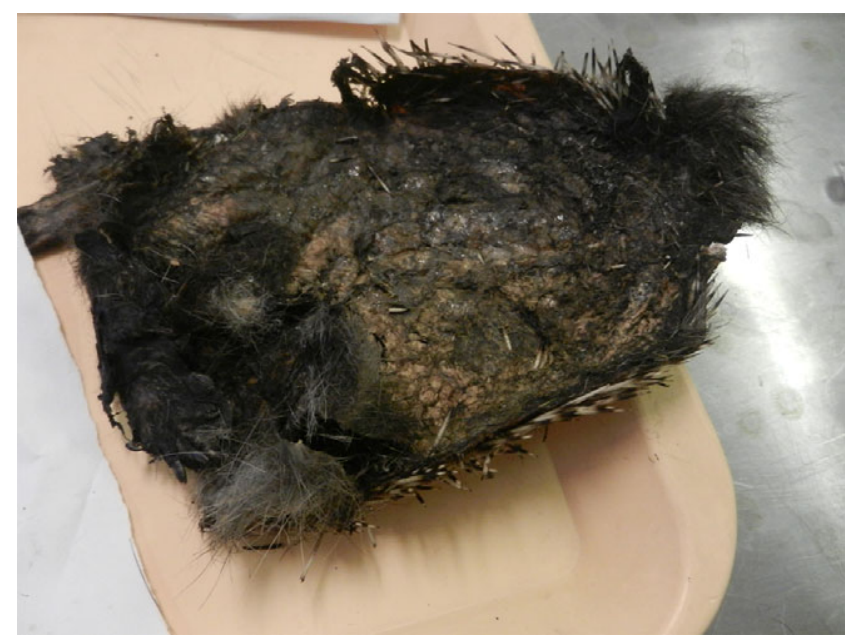

FIGURE 6 Flat and dry carcass of a road-killed northern whitebreasted hedgehog with unrecognizable organs (degree of degradation 5) [Colour figure can be viewed at wileyonlinelibrary.com]

included into the study. We collected carcasses of animals struck and killed by motor vehicles on highways $(n=29)$ or accidentally killed animals, e.g., killed by cat $(n=6)$ from urbanized habitats, mainly from Budapest, Hungary (Figure 1; Supporting Information Table S1).

All the removed ticks were from nine hedgehogs (Figure 2); the other carcasses did not harbour any ticks. The maximum number of ticks/host was 219 (Table 1). We collected 417 ticks, 55 Ixodes hexagonus (7 larvae, 46 nymphs, 2 females), and 362 I. ricinus (37 larvae, 278 nymphs, 16 males, 31 females). Two hedgehogs were infested with 
TABLE 3 Detection of tick-borne bacterial pathogens with real-time PCR in tissue samples according to the degree of degradation of the carcasses

\begin{tabular}{|c|c|c|c|c|c|c|c|c|c|c|}
\hline Sample type & $\begin{array}{l}\text { Degree of } \\
\text { degradation } \\
(1-5)^{a}\end{array}$ & $\begin{array}{l}\text { Number } \\
\text { of host } \\
\text { individuals }\end{array}$ & $\begin{array}{l}\text { Number of } \\
\text { collected } \\
\text { samples }\end{array}$ & $\begin{array}{l}\text { Anaplasma } \\
\text { phagocytophilum }\end{array}$ & $\begin{array}{l}\text { Borrelia } \\
\text { burgdorferi } \\
\text { s.l. }\end{array}$ & $\begin{array}{l}\text { Borrelia } \\
\text { miyamotoi }\end{array}$ & $\begin{array}{l}\text { Rickettsia } \\
\text { helvetica }\end{array}$ & $\begin{array}{l}\text { Rickettsia } \\
\text { sp. }\end{array}$ & $\begin{array}{l}\text { Bartonella } \\
\text { sp. }\end{array}$ & $\begin{array}{l}\text { Number } \\
\text { of positive } \\
\text { samples }^{b}\end{array}$ \\
\hline \multirow[t]{4}{*}{ Hedgehogs } & 1 & 4 & 16 & 4 & 2 & - & 3 & 4 & 2 & 15 \\
\hline & 2 & 2 & 4 & 1 & 1 & - & 2 & 2 & 1 & 7 \\
\hline & 3 & 6 & 10 & 5 & 3 & - & 5 & 5 & 1 & 19 \\
\hline & 4 & 5 & 8 & 3 & - & - & 2 & 2 & - & 7 \\
\hline \multirow[t]{3}{*}{ Other species ${ }^{c}$} & 1 & 10 & 33 & 1 & 1 & 1 & 1 & 3 & 4 & 11 \\
\hline & 3 & 1 & 3 & 1 & - & - & - & - & - & 1 \\
\hline & 4 & 1 & 3 & - & - & - & 1 & - & - & 1 \\
\hline
\end{tabular}

aDegree of degradation: 1-intact perfect condition for internal organ tissue collection at most skull crashed; 2-crushed body with mostly intact internal organs; 3-partly smashed internal organs; 4-smashed internal organs, only muscle and skin tissue, semi-dry carcass; 5-flat and dry carcass with unrecognizable organs (except skin). ${ }^{\text {b}}$ The number of positive samples for the pathogens is higher than the collected sample number at a given degree of degradation, because one sample can be positive for more than one pathogen. 'See details in Supporting Information Table S1.

TAB LE 4 Prevalence of tick-borne pathogens in ticks removed from road-killed hedgehogs detected with real-time PCR. Borrelia miyamotoi and Can. N. mikurensis were not detected in any on-host ticks

\begin{tabular}{|c|c|c|c|c|c|}
\hline \multicolumn{2}{|c|}{ Tick species and stage } & Borrelia burgdorferi s.l. & Anaplasma phagocytophilum & Rickettsia helvetica & Rickettsia sp. \\
\hline \multirow[t]{4}{*}{ Ixodes ricinus } & Female & $10 / 31 / 32 \%$ & $23 / 31 / 74 \%$ & $19 / 31 / 61 \%$ & $26 / 31 / 84 \%$ \\
\hline & Male & $6 / 16 / 38 \%$ & $8 / 16 / 50 \%$ & $7 / 16 / 44 \%$ & $10 / 16 / 63 \%$ \\
\hline & Nymph $^{a}$ & $34 / 59 / 17 \%$ & $54 / 59 / 45 \%$ & $34 / 59 / 17 \%$ & $44 / 59 / 26 \%$ \\
\hline & $\operatorname{Larva}^{a}$ & $2 / 5 / 6.4 \%$ & $5 / 5 / 7 \%$ & $3 / 5 / 10 \%$ & $3 / 5 / 10 \%$ \\
\hline \multirow{2}{*}{ Ixodes hexagonus } & Nymph $^{a}$ & $1 / 10 / 2 \%$ & $9 / 10 / 54 \%$ & $3 / 10 / 7 \%$ & $6 / 10 / 19 \%$ \\
\hline & Larva $^{a}$ & $0 / 1 / 0 \%$ & $1 / 1 / 96 \%$ & $0 / 1 / 0 \%$ & $0 / 1 / 0 \%$ \\
\hline \multicolumn{2}{|l|}{ Sum* } & $51 / 124 / 16 \%$ & $101 / 124 / 24 \%$ & $66 / 124 / 21 \%$ & $89 / 124 / 33 \%$ \\
\hline
\end{tabular}

Bold values indicate prevalence data.

${ }^{a}$ Minimum infection rate (up to 5 nymphs/pool; up to 10 larvae/pool).

both tick species and seven hedgehogs were infested with only I. ricinus (Table 1). From the 417 removed ticks, 124 samples were created and assayed (111 I. ricinus and $13 \mathrm{l}$. hexagonus individual or pooled samples).

From the carcasses, we collected 90 tissue samples for molecular analysis (52 from hedgehogs and 38 from the other species) (Table 2). The degree of degradation of the carcasses was different; some specimens were in "perfect" condition (Figures 3-5) with no sign of degradation (degree of degradation 1) and some were flat, dry (Figure 6) and heavily damaged by vehicles (degree of degradation 5) (Table 3).

\section{2 | Tick-borne pathogens in tissue samples}

All examined pathogens were detected in the collected mammal tissue samples except Can. N. mikurensis. Among the 23 collected hedgehog carcasses, 17 (74\%) were infected with A.phagocytophilum, 6 (26\%) with B. burgdorferi s.l., 12 (52\%) with R. helvetica, and 15 (65\%) with Rickettsia sp. Borrelia burgdorferi s.l. was detected in the muscle and skin of hedgehogs (12\%) and skin sample from a squirrel (Table 2). Borrelia miyamotoi was only detected in a squirrel spleen sample. Anaplasma phagocytophilum was found in muscle, skin, liver, spleen, and coagulated blood from hedgehogs (52\%); in the skin of a juvenile roe deer; and a lesser shrew muscle sample. Rickettsia helvetica DNA was amplified in skin, spleen, and muscle from hedgehogs (29\%); skin of a house mouse; and muscle of a stone marten. We found Rickettsia sp. positive in skin, spleen, liver, muscle, and coagulated blood of hedgehogs (37\%); skin of a house mouse and a mole; and a muscle sample of a lesser weasel. Bartonella species were detected in all tissue sample types of moles, skin samples of hedgehogs, muscle of a house mouse, and coagulated blood and muscle of a lesser weasel.

Pathogen prevalence data of different mammal species are shown in Table 2, and all data for positive samples from the small mammals are shown in the Supporting Information Table S1. Pathogen detection was possible from even the most degraded tissues (Table 3). 
TABLE 5 Specification of tick-borne pathogens in tissues samples from small- and medium-sized mammals and ticks removed from hedgehogs

\begin{tabular}{|c|c|c|c|c|c|}
\hline Sample type & Pathogen & Host/tick species & $\begin{array}{l}\text { Tissue type/tick } \\
\text { stage/sex }\end{array}$ & $\begin{array}{l}\text { Number of } \\
\text { samples }\end{array}$ & Accession numbers \\
\hline \multirow[t]{11}{*}{ Tissue } & Borrelia afzelii & $\begin{array}{l}\text { Northern white-breasted hedgehog } \\
\text { (Erinaceus roumanicus) }\end{array}$ & Skin & 1 & MF163403 \\
\hline & Borrelia spielmanii & $\begin{array}{l}\text { Northern white-breasted hedgehog } \\
\text { (E. roumanicus) }\end{array}$ & Muscle & 2 & MF163401, MF163402 \\
\hline & \multirow[t]{2}{*}{ Anaplasma phagocytophilum ecotype I } & \multirow{2}{*}{$\begin{array}{l}\text { Northern white-breasted hedgehog } \\
\text { (E. roumanicus) }\end{array}$} & Liver & 1 & MF372764 \\
\hline & & & Spleen & 3 & MF372767-MF372769 \\
\hline & \multirow[t]{7}{*}{ Bartonella sp. } & \multirow{2}{*}{$\begin{array}{l}\text { Northern white-breasted hedgehog } \\
\text { (E. roumanicus) }\end{array}$} & Muscle & 1 & MF372778 \\
\hline & & & Skin & 2 & MF372780, MF372781 \\
\hline & & House mouse (Mus musculus) & Muscle & 1 & MF372781 \\
\hline & & \multirow[t]{2}{*}{ European mole (Talpa europaea) } & Blood & 2 & MF372782, MF372786 \\
\hline & & & Spleen & 1 & MF372783 \\
\hline & & \multirow[t]{2}{*}{ Lesser weasel (Mustela nivalis) } & Blood & 1 & MF372790 \\
\hline & & & Spleen & 1 & MF372791 \\
\hline \multirow[t]{5}{*}{ Tick } & \multirow[t]{3}{*}{ Borrelia afzelii } & \multirow[t]{3}{*}{ Ixodes ricinus } & Female & 1 & MF163404 \\
\hline & & & Male & 1 & MF163405 \\
\hline & & & Nymph ${ }^{a}$ & 7 & MF163406-MF163412 \\
\hline & \multirow[t]{2}{*}{ Anaplasma phagocytophilum ecotype I } & \multirow[t]{2}{*}{ Ixodes ricinus } & Female & 2 & MF372771, MF372772 \\
\hline & & & Nymph $^{\mathrm{a}}$ & 5 & MF372773-MF372777 \\
\hline
\end{tabular}

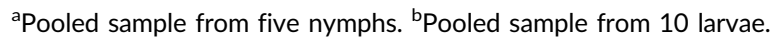

\subsection{Tick-borne pathogens in ticks removed from road-killed hedgehogs}

Borrelia miyamotoi and Can. N. mikurensis DNA were not detected in tick samples (Table 4). Borrelia burgdorferi s.l. was detected in $16 \%$ (minimum infection rate) of ticks; all stages of I. ricinus (female: $32 \%$, male: $38 \%$, nymph minimum infection rate: $17 \%$, larva minimum infection rate: $6 \%$ ) and $I$. hexagonus nymphs (minimum infection rate: $2 \%)$. Anaplasma phagocytophilum was represented in all stages of both tick species with relatively high percentage (Table 4). Rickettsia helvetica was found in I. ricinus females, males, nymphs, and larvae and in $I$. hexagonus nymphs with an overall $R$. helvetica prevalence of $20.5 \%$ (minimum infection rate) in ticks. Rickettsia sp. was found in all stages of $I$. ricinus and $I$. hexagonus nymphs. Pathogen prevalence in ticks is presented in Table 4.

\subsection{Pathogen identification}

The qPCR-positive samples were also amplified with specific conventional PCR assays and were sequenced if needed. Borrelia afzelii was found in one I. ricinus female, one male, and seven nymphal pools. Anaplasma phagocytophilum ecotype I was found in two females and five I. ricinus nymphal pools and one I. hexagonus female. Rickettsia monacensis occurred in four I. ricinus nymphal pools and a larval pool. Borrelia afzelii and B. spielmanii were found only in hedgehog skin and muscle. Anaplasma phagocytophilum was detected in liver, skin, and spleen samples from hedgehogs. Bartonella species DNA was amplified in E. roumanicus (muscle, skin), house mouse (muscle), mole (coagulated blood, liver, muscle, skin, spleen), and lesser weasel (coagulated blood, spleen) tissues. Positive samples were sequenced and a BLAST search was performed using GenBank. The identified pathogens are shown in Table 5. The highest similarity in the case of Bartonella sequences was found with a Bartonella taylorii (98\%) sequence from a plateau pika (Ochotona curzoniae; Tibetian plateau, China; accession numbers: KT445922; KT445921; KT445919) (Rao et al., 2015) and 97\% with a Bartonella sp. sequence from Yunnan redbacked vole (Eothenomys miletus; Yunnan, China; accession number: AF391281) (Ying, Kosoy, Maupin, Tsuchiya, \& Gage, 2002). The other hits with lower scores were "Uncultured" Bartonella sp. and Bartonella sp. sequences. Thus, we made a BLAST search with one of the above 
three similar B. taylorii sequences and unfortunately, it showed similarity only with the other two but none of the more than ten $B$. taylorii gltA sequences in the GenBank submitted by others. For this reason, we considered our sequences as Bartonella spp.

All identified pathogens and accession numbers are shown in Table 5.

\section{DISCUSSION}

The green areas of cities, like suburban forests, cemeteries, and city parks, are suitable habitats for several wildlife species. These mammals can serve as hosts for ticks and tick-borne pathogens with medical and veterinary importance (Rizzoli et al., 2014). Our study sheds light on the diversity and composition of tick-borne bacterial communities in accidentally and road-killed urban mammals. These baseline data can be used in further eco-epidemiological studies and thus might help in the prevention of tick-borne pathogens.

Using road-killed animals as sources of tissue samples and ectoparasites provides both advantages and disadvantages. It is possible to collect samples not only from common species but also from internal organs of animals under protection and thus neglected in eco-epidemiological studies. A further advantage of using roadkill versus surveying wildlife through live capture or hunting is that both organization and logistics requires much less resources. In contrast, the main disadvantage is the varying condition of the carcasses. It is possible to collect dead animals in very good conditions, but carcasses are often dried samples with unidentifiable organs (except of skin) and bodies fully flattened by cars. The PCR reaction could be false-negative because of the high degree of degradation (inhibitors and DNA degradation) and the rise of decomposing bacteria. However, despite the highest degree of degradation (4 or 5 ) it was possible to amplify DNA of $A$. phagocytophilum, $R$. helvetica, and Rickettsia sp. in dried skin and muscle samples from road- and accidentally killed urban animals with real-time PCR. Therefore, even badly damaged carcasses might provide important baseline information on the presence and prevalence of a pathogen in urban habitats. The opportunistic manner of this sample collection does not allow, however, for the collection of all species of interest and, might also bias results. Since the number of specimens from each species collected cannot be determined in advance, species with limited number of samples allow no or only limited conclusions regarding the role of the host in the circulation of particular pathogen. We are also aware that some ectoparasites had already left the host by the time they were sampled, thus only a fraction of them will be found and processed.

We found six different pathogens in 90 collected tissue samples from eight mammal species (Table 2). Besides several single infections $(n=7)$, double $(n=10)$, triple $(n=5)$, quadruple $(n=5)$ infections, and one quintuple infection occurred in the collected animal tissues. Most of the multiple infections (28 tissue samples) were found in hedgehogs but double infections also occurred in the other collected mammal species (lesser weasel, European red squirrel, and house mouse) (Supporting Information Table S1).
Some road-killed mammals also proved to be a good source of ixodid ticks: 417 ticks were removed from nine carcasses, all of them were hedgehogs (362 I. ricinus and $55 \mathrm{I}$. hexagonus). The sample size in other species was small thus further sampling has to clarify whether hedgehogs tend to harbour more ticks compared to the other small mammal species in urban habitats. Four different pathogens were identified with real-time PCR within these ectoparasites (Table 4). While the pathogens detected from feeding ticks might only be part of their blood meal, the lack of Can. N. mikurensis and $B$. miyamotoi in them can mean that $E$. roumanicus has probably no (B. miyamotoi) or limited (Can. N. mikurensis) role in the maintenance of these bacteria as suggested by the present and previous (Földvári et al., 2014) findings regarding hedgehog tissues.

Anaplasma phagocytophilum ecotype I, which is the most prevalent human pathogenic ecotype, was found in northern white-breasted hedgehog tissue samples and in I. ricinus and $I$. hexagonus ticks. Some of the removed ticks from the $A$. phagocytophilum-positive hedgehogs were also infected with A. phagocytophilum. In addition, some hedgehogs were positive for A. phagocytophilum and their ticks were negative, and there were some positive tick samples from negative hedgehogs as well. These findings are not surprising, since transmission efficacy during feeding might be less than $100 \%$ and A. phagocytophilum has transstadial transmission (Sonenshine \& Roe, 2014). These two ectoparasite species are the most prevalent ticks feeding on hedgehogs and they also have an important role in the eco-epidemiology of Lyme borreliosis (Rizzoli et al., 2014; Szekeres, Majláthová, Majláth, \& Földvári, 2016). In a previous study about urban hedgehogs from a park in Budapest, Hungary A. phagocytophilum prevalence was similarly high (76\%) as in the present study (74\%) (Földvári et al., 2014). The data that the human pathogenic A. phagocytophilum ecotype I was detected in hedgehogs, and with high prevalence in both tick species removed from them (mean minimum infection rate: $56 \%$ ) strongly suggest the maintenance role of E. roumanicus in the A. phagocytophilum cycles (Földvári et al., 2014; Jahfari et al., 2017). This is the first report of $A$. phagocytophilum in tissues from lesser shrew. Xenodiagnostic laboratory experiments could ascertain the reservoir role of these hosts (Kahl, Gern, Eisen, \& Lane, 2002).

One roe deer fawn skin sample was positive with $A$. phagocytophilum specific real-time PCR. In roe deer A. phagocytophilum infection was reported in several European countries (Jahfari et al., 2014). Our finding is interesting, however, because the fawn hit by a car was at an early age (approximately 2 weeks), it had a short time-period to acquire infection via tick bite. During the dissection, no ectoparasite was found on this carcass. These circumstances suggest that transplacental transmission might be possible not just in sheep (Reppert et al., 2013) but also in wild ruminants like roe deer as well.

Borrelia afzelii was found in hedgehog skin and I. ricinus samples (female, male, nymph) and B. spielmanii in muscle samples from hedgehogs. Both Borrelia species cause erythema migrans in humans (Földvári, Farkas, \& Lakos, 2005; Szekeres et al., 2015a,b). Similar with E. europaeus, E. roumanicus probably has reservoir role for Lyme borreliosis spirochaetes, which has not yet been demonstrated with xenodiagnostic experiments. A recent study from the Czech Republic 
also identified B. afzelii as the most common genospecies in questing I. ricinus also within urban habitats (Kybicová, Baštová, \& Malý, 2017).

Rickettsia monacensis was found in I. ricinus nymphs and one larval pool, and $R$. helvetica was detected in all stages of I. ricinus and $I$. hexagonus nymph samples with relatively high prevalence. These two bacteria are human pathogens (Fournier, Grunnenberger, Jaulhac, Gastinger, \& Raoult, 2000; Jado et al., 2007), belonging to the Mediterranean spotted fever group rickettsiae causing elevated fever, eschar, and maculopapular rash. In hedgehogs, moles, a mouse, a lesser weasel, and a stone marten, rickettsiae were detected. This is the first report about Rickettsia sp. infection in European moles and lesser weasel and about $R$. helvetica in stone marten. Xenodiagnostic experiments are required to determine whether these hosts play a reservoir role in the urban cycle of these pathogens.

We detected one B. miyamotoi positive spleen sample from a European red squirrel, a similar observation was recently reported from Belgium (Ruyts, Frazer-Mendelewska, Van Den Berge, Verheyen, \& Sprong, 2017). The presence of B. miyamotoi and the high prevalence of B. burgdorferi s.l. (Pisanu et al., 2014) in red squirrels suggest this species might have a role in the cycles of these Borrelia species (Szekeres et al., 2016). Borrelia miyamotoi is an emerging pathogen reported from many countries in ticks, hosts, and also humans (Wagemakers, Staarink, Sprong, \& Hovius, 2015). The reported number of human disease cases is increasing in the Northern Hemisphere (USA, Russia, Japan, Germany, the Netherlands) (Boden, Lobenstein, Hermann, Margos, \& Fingerle, 2016; Chowdri et al., 2013; Gugliotta, Goethert, \& Berardi, 2013; Hovius et al., 2013; Krause et al., 2013; Platonov et al., 2011; Sato et al., 2014).

Northern white-breasted hedgehogs, one house mouse, two European moles, and a lesser weasel were Bartonella spp. specific PCR positive. The eco-epidemiology of these bacteria such as vector species and reservoir animals are unknown.

In $I$. hexagonus nymphs we found for the first time $R$. helvetica and Rickettsia sp. pathogens. There was a report about rickettsiae infection in I. ricinus and I. hexagonus, but unfortunately it was not clear, whether I. hexagonus truly carried any Rickettsia pathogens (Giroud, Capponi, Dumas, \& Rageau, 1965). The relatively high A. phagocytophilum (min. prev.: 22\%), in I. hexagonus samples might indicate that, this tick species can have a role in the endophilic pathogen cycle of tick-borne pathogens (Szekeres et al., 2015a,b). However, as all I. hexagonus were removed from two A. phagocytophilum, $R$. helvetica and Rickettsia sp. real-time PCR positive hedgehogs (code: $\mathrm{H} 4$ and $\mathrm{H} 16$ ), the pathogens might as well be only part of the tick's blood meal. Xenodiagnostic experiments are needed to clarify the vector role of these tick species in the future.

\section{5 | CONCLUSIONS}

Environmental change in general, but urbanization specifically leads to a change in the dynamics of hosts, vectors, and pathogens. Therefore, monitoring potential reservoirs, vectors, and pathogens within cities is recommended. Accidentally killed and road-killed animals are simple and reasonable resources (with known limitations) that can be utilized to this end. Our molecular analyses showed that hedgehogs, moles, shrews, squirrels, mice, martens, and weasels are carriers of one or several tick-borne pathogens in urban habitats. We also highlight the importance of documentation and assessment of pathogen prevalence and diversity in carrier hosts and their ectoparasites which is a prerequisite for the risk assessment for emerging infectious diseases (see DAMA protocol in (Brooks et al., 2014). Due to the high motility of these urban mammals within and between human settlements, we expect an enhanced spread of ticks and tick-borne pathogens that represent high risk wherever these mammals are found and as long as habitats are suitable for tick survival as well. Further studies should investigate their relative contribution to the maintenance and spread of these pathogens and specify their relative roles in the incidence of human tick bites and tick-borne diseases.

\section{ACKNOWLEDGEMENTS}

S. Sz. was supported by the Hungarian Eötvös Scholarship and EurNegVec Cost Action TD1303. G. F. was supported by the János Bolyai Research Scholarship of the Hungarian Academy of Sciences. This study was supported by the grants 11475-4/2016/FEKUT and 12190/2017/FEKUTSTRAT of the Hungarian Ministry of Human Resources and the grant "In the light of evolution: theories and solutions" (GINOP-2.3.2-15-2016-00057). We are grateful for the help of all the volunteers who contributed in any way to the collection of the carcasses. We are grateful to Daniel R. Brooks and Mihály Földvári for proofreading and for their valuable comments.

\section{CONFLICT OF INTEREST}

The authors declare that they have no conflict of interest.

\section{ORCID}

Gábor Földvári iD http://orcid.org/0000-0001-5297-9036

\section{REFERENCES}

Boden, K., Lobenstein, S., Hermann, B., Margos, G., \& Fingerle, V. (2016). Borrelia miyamotoi - Associated Neuroborreliosis in Immunocompromised Person. Emerging Infectious Diseases, 22, 1617-1620. https:// doi.org/10.3201/eid2208.152034

Brooks, D. R., Hoberg, E. P., Boeger, W. A., Gardner, S. L., Galbreath, K. E., Herczeg, D., ... Dursahinhan, A. T. (2014). Finding them before they find us: Informatics, parasites, and environments in accelerating climate change. Comparative Parasitology, 81, 155-164. https://doi. org/10.1654/4724b.1

de Bruin, A., van Leeuwen, A. D., Jahfari, S., Takken, W., Földvári, M., Dremmel, L., ... Földvári, G. (2015). Vertical transmission of Bartonella schoenbuchensis in Lipoptena cervi. Parasites and Vectors, 8, 176. https://doi.org/10.1186/s13071-015-0764-y 
Chowdri, H. R., Gugliotta, J. L., Berardi, V. P., Goethert, H. K., Molloy, P. J., Sterling, S. L., \& Telford, S. R. (2013). Borrelia miyamotoi infection presenting as human granulocytic anaplasmosis: a case report. Annals of Internal Medicine, 159, 21-27. https://doi.org/10.7326/00034819-159-1-201307020-00005

Courtney, J. W., Kostelnik, L. M., Zeidner, N. S., \& Massung, R. F. (2004). Multiplex real-time PCR for detection of Anaplasma phagocytophilum and Borrelia burgdorferi. Journal of Clinical Microbiology, 42, 3164 3168. https://doi.org/10.1128/jcm.42.7.3164

Földvári, G., Farkas, R., \& Lakos, A. (2005). Borrelia spielmanii Erythema Migrans, Hungary. Emerging Infectious Diseases, 11, 1794-1795. https://doi.org/10.3201/eid1111.050542

Földvári, G., Jahfari, S., Rigó, K., Jablonszky, M., Szekeres, S., Majoros, G., ... Sprong, H. (2014). Candidatus Neoehrlichia mikurensis and Anaplasma phagocytophilum in Urban Hedgehogs. Emerging Infectious Diseases, 20, 496-498.

Földvári, G., Rigó, K., Jablonszky, M., Biró, N., Majoros, G., Molnár, V., \& Tóth, M. (2011). Ticks and the city: Ectoparasites of the Northern white-breasted hedgehog (Erinaceus roumanicus) in an urban park. Ticks and Tick-borne Diseases, 2, 231-234. https://doi.org/10.1016/j. ttbdis.2011.09.001

Fournier, P.-E., Grunnenberger, F., Jaulhac, B., Gastinger, G., \& Raoult, D. (2000). Evidence of Rickettsia helvetica infection in humans, Eastern France. Emerging Infectious Diseases, 6, 389-392. https://doi.org/10. 3201/eid0604.000412

Giroud, P., Capponi, M., Dumas, N., \& Rageau, J. (1965). Les Ixodes ricinus et hexagonus de France contiennent des agents rickettsiens ou proches. Comptes Rendus Hebdomadaires des Séances de l'Académie des Sciences, 260, 4874-4876.

Gugliotta, J. L., Goethert, H. K., Berardi, V. P., \& S.R. 3rd Telford, (2013). Meningoencephalitis from Borrelia miyamotoi in an immunocompromised patient. New England Journal of Medicine, 368, 240-245. https://doi.org/10.1056/NEJMoa1209039

Guy, E. C., \& Stanek, G. (1991). Detection of Borrelia burgdorferi in patients with Lyme disease by the polymerase chain reaction. Journal of Clinical Pathology, 44, 610-611. https://doi.org/10.1136/jcp.44.7.610

Hansford, K. M., Fonville, M., Jahfari, S., Sprong, H., \& Medlock, J. M. (2015). Borrelia miyamotoi in host-seeking Ixodes ricinus ticks in England. Epidemiology and Infection, 143, 1079-1087. https://doi.org/10. 1017/S0950268814001691

Heylen, D., Tijsse, E., Fonville, M., Matthysen, E., \& Sprong, H. (2013). Transmission dynamics of Borrelia burgdorferi s.l. in a bird tick community. Environmental Microbiology, 15, 6636-6673. https://doi.org/ 10.1111/1462-2920.12059

Hillyard, P. (1996). Ticks of North-West Europe. Shrewsbury: Field Studies Council.

Hornok, S., Földvári, G., Rigó, K., Meli, M. L., Gönczi, E., Répási, A., ... Hofmann-Lehmann, R. (2015). Synanthropic rodents and their ectoparasites as carriers of a novel haemoplasma and vector-borne, zoonotic pathogens indoors. Parasites and Vectors, 8, 27. https://doi. org/10.1186/s13071-014-0630-3

Hornok, S., Kováts, D., Csörgô, T., Meli, M. L., Gönczi, E., Hadnagy, Z., ... Hofmann-Lehmann, R. (2014). Birds as potential reservoirs of tickborne pathogens: First evidence of bacteraemia with Rickettsia helvetica. Parasites and Vectors, 7, 128. https://doi.org/10.1186/17563305-7-128

Hovius, J. W. R., de Wever, B., Sohne, M., Brouwer, M. C., Coumou, J., Wagemakers, A., ... van Oers, M. H. J. (2013). A case of meningoencephalitis by the relapsing fever spirochaete Borrelia miyamotoi in Europe. Lancet, 382, 658. https://doi.org/10.1016/S0140-6736(13) 61644-X

Jado, I., Oteo, J. A., Aldámiz, M., Gil, H., Escudero, R., García-amil, C., ... Anda, P. (2007). Rickettsia monacensis and Human Disease, Spain. Emerging Infectious Diseases, 13, 1405-1407. https://doi.org/10. 3201/eid1309.060186
Jahfari, S., Coipan, E. C., Fonville, M., Docters van Leeuwen, A., Hengeveld, P., Heylen, D., ... Sprong, H. (2014). Circulation of four Anaplasma phagocytophilum ecotypes in Europe. Parasites and Vectors, 7 , 365. https://doi.org/10.1186/1756-3305-7-365

Jahfari, S., Fonville, M., Hengeveld, P., Reusken, C., Scholte, E. J., Takken, W., ... Sprong, H. (2012). Prevalence of Neoehrlichia mikurensis in ticks and rodents from North-west Europe. Parasites and Vectors, 5, 74. https://doi.org/10.1186/1756-3305-5-74

Jahfari, S., Ruyts, S. C., Frazer-Mendelewska, E., Jaarsma, R., Verheyen, K., \& Sprong, H. (2017). Melting pot of tick-borne zoonoses: The European hedgehog contributes to the maintenance of various tick-borne diseases in natural cycles urban and suburban areas. Parasites and Vectors, 10, 134. https://doi.org/10.1186/s13071017-2065-0

Kahl, O., Gern, L., Eisen, L., \& Lane, R. S. (2002). Ecological research on Borrelia burgdorferi sensu lato: Terminology and some methodological pitfalls. In J. Gray, O. Kahl, R. S. Lane, \& G. Stanek (Eds.), Lyme borreliosis: Biology, Epidemiology and Control (pp. 29-46). Bristol: CABI. https://doi.org/10.1079/9780851996325.0000

Krause, P. J., Narasimhan, S., Wormser, G. P., Rollend, L., Fikrig, E., Lepore, T., ... Fish, D. (2013). Human Borrelia miyamotoi infection in the United States. New England Journal of Medicine, 368, 291-293. https://doi.org/10.1056/NEJMc1215469

Krawczyk, A. I., van Leeuwen, A. D., Jacobs-Reitsma, W., Wijnands, L. M., Bouw, E., Jahfari, S., ... de Bruin, A. (2015). Presence of zoonotic agents in engorged ticks and hedgehog faeces from Erinaceus europaeus in (sub) urban areas. Parasites and Vectors, 8, 210. https://doi. org/10.1186/s13071-015-0814-5

Kybicová, K., Baštová, K., \& Malý, M. (2017). Detection of Borrelia burgdorferi sensu lato and Anaplasma phagocytophilum in questing ticks Ixodes ricinus from the Czech Republic. Ticks and Tick-borne Diseases, 8, 483-487. https://doi.org/10.1016/j.ttbdis.2017.02.007

Nosek, J., \& Sixl, W. (1972). Central-European Ticks (Ixodoidea) - Key for determination-. Mitteilungen der Abteilung für Zoologie am Landesmuseum Joanneum, 1, 61-92.

Pisanu, B., Chapuis, J.-L., Dozières, A., Basset, F., Poux, V., \& Vourc'h, G. (2014). High prevalence of Borrelia burgdorferi s.l. in the European red squirrel Sciurus vulgaris in France. Ticks and Tick-borne Diseases, 5, 1-6. https://doi.org/10.1016/j.ttbdis.2013.07.007

Platonov, A. E., Karan, L. S., Kolyasnikova, N. M., Makhneva, N. A., Toporkova, M. G., Maleev, V. V., ... Krause, P. J. (2011). Humans infected with relapsing fever spirochete Borrelia miyamotoi, Russia. Emerging Infectious Diseases, 17, 1816-1823. https://doi.org/10. 3201/eid1710.101474

Rao, H. X., Yu, J., Guo, P., Ma, Y. C., Liu, Q. Y., Jiao, M., ... Li, D. M. (2015). Bartonella Species Detected in the Plateau Pikas (Ochotona curzoiae) from Qinghai Plateau in China. Biomedical and Environmental Sciences, 28, 674-678. https://doi.org/10.3967/bes2015.094. Nethe rlands

Reeve, N. (1994). Hedgehogs. London: T \& AD Poyser (Natural History).

Reppert, E., Galindo, R. C., Breshears, M. A., Kocan, K. M., Blouin, E. F., \& de la Fuente, J. (2013). Demonstration of transplacental transmission of a human isolate of Anaplasma phagocytophilum in an experimentally infected sheep. Transboundary and Emerging Diseases, 60, 93-96. https://doi.org/10.1111/tbed.12120

Rizzoli, A., Silaghi, C., Obiegala, A., Rudolf, I., Hubalek, Z., Földvári, G., ... Kazimi-rová, M. (2014). Ixodes ricinus and its transmitted pathogens in urban and peri-urban areas in Europe: New hazards and relevance for public health. Frontiers in Public Health, 2, 251. https://doi.org/10. 3389/fpubh.2014.00251

Roux, V., \& Raoult, D. (2000). Phylogenetic analysis of members of the genus Rickettsia using the gene encoding the outer-membrane protein rOmp (ompB). International Journal of Systematic and Evolutionary Microbiology, 50, 1449-1455. https://doi.org/10.1099/0020771350-4-1449 
Ruyts, S. C., Frazer-Mendelewska, E., Van Den Berge, K., Verheyen, K. \& Sprong, H. (2017). Molecular detection of tick-borne pathogens Borrelia afzelii, Borrelia miyamotoi and Anaplasma phagocytophilum in Eurasian red squirrels (Sciurus vulgaris). European Journal of Wildlife Research, 63, 9-12. https://doi.org/10.1007/s10344-0171104-7

Sato, K., Takano, A., Konnai, S., Nakao, M., Ito, T., Koyama, K., ... Kawabata, H. (2014). Human infections with Borrelia miyamotoi, Japan. Emerging Infectious Diseases, 20, 1391-1393. https://doi.org/10. 3201/eid2008.131761

Sonenshine, D., \& Roe, R. (Eds.) (2014). Biology of Ticks. Oxford, UK: Oxford University Press.

Stenos, J., Graves, S. R., \& Unsworth, N. B. (2005). A highly sensitive and specific real-time PCR assay for the detection of spotted fever and typhus group Rickettsiae. American Journal of Tropical Medicine and Hygiene, 73, 1083-1085. https://doi.org/10.4269/ajtmh.2005.73. 1083

Szekeres, S., Coipan, E. C., Rigó, K., Majoros, G., Jahfari, S., Sprong, H., \& Földvári, G. (2015a). Eco-epidemiology of Borrelia miyamotoi and Lyme borreliosis spirochetes in a popular hunting and recreational forest area in Hungary. Parasites and Vectors, 8, 309. https://doi.org/ 10.1186/s13071-015-0922-2

Szekeres, S., Coipan, E. C., Rigó, K., Majoros, G., Jahfari, S., Sprong, H., \& Földvári, G. (2015b). Candidatus Neoehrlichia mikurensis and Anaplasma phagocytophilum in natural rodent and tick communities in Southern Hungary. Ticks and Tick-borne Diseases, 6, 111-116. https://doi.org/10.1016/j.ttbdis.2014.10.004

Szekeres, S., Majláthová, V., Majláth, I., \& Földvári, G. (2016). Neglected hosts: The role of lacertid lizards and medium-sized mammals in the eco-epidemiology of Lyme borreliosis. In M. A. H. Braks, vanWieren S. E., W. Takken \& H. Sprong (Eds.), Ecology and prevention of Lyme borreliosis (Ecology and Control of Vector-borne diseases, Vol. 4) (pp. 103-126). Wageningen: Wageningen Academic Publishers. https:// doi.org/10.3920/227-1875-0699
Tolnai, Z., Sréter-Lancz, Z., \& Sréter, T. (2015). Spatial distribution of Anaplasma phagocytophilum and Hepatozoon canis in red foxes (Vulpes vulpes) in Hungary. Ticks and Tick-borne Diseases, 6, 645-648. https://doi.org/10.1016/j.ttbdis.2015.05.009

Tóth-Ronkay, M., Bajor, Z., Bárány, A., Földvári, G., Görföl, T., Halpern, B., ... Vörös, J. (2015). Budapest. In J. G. Kelcey (Ed.), Vertebrates and invertebrates of European cities: Selected non-avian Fauna (pp. 26-73). Berlin: Springer Verlag.

Wagemakers, A., Staarink, P. J., Sprong, H., \& Hovius, J. W. R. (2015). Borrelia miyamotoi: A widespread tick-borne relapsing fever spirochete. Trends in Parasitology, 31, 260-269. https://doi.org/10.1016/j. pt.2015.03.008

Ying, B., Kosoy, M. Y., Maupin, G. O., Tsuchiya, K. R., \& Gage, K. L. (2002). Genetic and ecologic characteristics of Bartonella communities in rodents in Southern China. American Journal of Tropical Medicine and Hygiene, 66, 622-627. https://doi.org/10.4269/ajtmh.2002. 66.622

\section{SUPPORTING INFORMATION}

Additional supporting information may be found online in the Supporting Information section at the end of the article.

How to cite this article: Szekeres S, van Leeuwen AD, Tóth E, Majoros G, Sprong H, Földvári G. Road-killed mammals provide insight into tick-borne bacterial pathogen communities within urban habitats. Transbound Emerg Dis. 2019;66:277-286. https://doi.org/10.1111/tbed.13019 